\title{
Contrapontos da história da hanseníase no Brasil: cenários de estigma e confinamento*
}

\author{
Luiz Antonio de Castro Santos ${ }^{\star *}$ \\ Lina Faria*** \\ Ricardo Fernandes de Menezes ${ }^{\star \star \star \star}$
}

\begin{abstract}
Ao discutir a luta contra a hanseníase no Brasil, em especial em São Paulo e no Maranhão, o trabalho focaliza as múltiplas formas da história institucional e da "cultura de reclusão" dos hansenianos. Critica-se a visão corrente de um cenário único de disciplina e vigilância para, ao contrário, sugerir a existência de cenários cambiantes, marcados por conflitos, negociações e distintas propostas de prevenção ou de combate à doença. O texto aborda as diferentes concepções médicas e "profanas" da lepra, bem como as propostas e práticas de intervenção social no Brasil e, em particular, nos estados de São Paulo e do Maranhão, desde os primeiros tempos da República até as primeiras décadas da Era Vargas. O combate à doença sempre desafiou conceitos e convicções sobre tratamento, propagação, confinamento e regeneração, sob múltiplos significados epidemiológicos, médicos, culturais e sociais, referidos ao estigma da doença, do pecado e da impureza. O texto procura estabelecer alguns cenários brasileiros nos quais se revelam as identidades coletivas deterioradas, a exclusão social e as políticas de confinamento institucional e de regeneração dos doentes.
\end{abstract}

Palavras-chave: Hanseníase. São Paulo. Maranhão. Brasil. Primeira República. Estado Novo. Identidades deterioradas. Políticas de confinamento.

Vi alguns pacientes que estavam doentes há dez e doze anos, já medonhamente desfigurados, mas suportavam [a moléstia] alegremente. Parece que, de fato, um espírito cheio de esperança, e uma vida livre e generosa, foram os meios de retardar os efeitos da moléstia; mas não sei de ninguém que se tivesse curado.

(Henry Walter Bates, The naturalist on the River Amazon, 1863)

Conhecida há séculos como uma moléstia que caminha lentamente, com alterações morfológicas e fisiológicas, até hoje a hanseníase desafia conceitos e convicções sobre tratamento e propagação. A doença passou a fazer parte da dramaturgia do sofrimento humano desde a Antigüidade, mas sua identidade etiológica remonta apenas ao final do século XIX, quando o médico norueguês Gerhard Henrik Armauer Hansen,

\footnotetext{
* Os autores agradecem a Juliane Serres e Patrícia Portela Nunes, pela documentação preciosa sobre o Maranhão, a Sylvia Ripper, pelas informações sobre o Regulamento do DNSP, de 1923, bem como à bolsista de Iniciação Científica, Jamile Rodrigues, pela pesquisa de fontes para o projeto Caminhos da Saúde Pública no Brasil, no Instituto de Medicina Social da UERJ.

** Sociólogo, PhD em Sociologia pela Universidade de Harvard. Professor adjunto do Instituto de Medicina Social da UERJ.

${ }_{* \star \star}$ Historiadora, Doutora em Saúde Coletiva (IMS/UERJ), com Pós-Doutorado em Política Científica e Tecnológica (DPCT/ Unicamp). Pesquisadora do Instituto de Medicina Social da UERJ.

**** Médico sanitarista da Secretaria de Estado da Saúde de São Paulo e da Secretaria Municipal de Saúde de São Paulo. Especialista em Saúde Pública pela Faculdade de Saúde Pública da USP, onde cursa atualmente a pós-graduação (mestrado) em sua especialidade.
} 
ao analisar material de lesões cutâneas, descobriu a Mycobacterium leprae, bacilo causador da doença e que pertence ao mesmo gênero do bacilo que ocasiona a tuberculose. A falta de conhecimentos clínico-imunológicos ensejou, antes da descoberta, hipóteses que apontavam o caráter hereditário da hanseníase. Em inícios do século XX, começou a ser vista como uma "enfermidade" merecedora de atenção médico-social, de acumulação de conhecimentos científicos e de medidas de contenção. Mas os aspectos cognitivos, preventivos e terapêuticos representaram, como poucas enfermidades daquela época, um terreno movediço e sujeito a profundas controvérsias.

Hoje, o estudioso não deverá surpreender-se ao constatar que, a despeito de a descoberta de Hansen remontar a 1873, a lepra não constou, por muito tempo, das relações de doenças de notificação compulsória no Brasil.

O presente trabalho focaliza, inicialmente, o surgimento da hanseníase no cenário do Brasil republicano. Este é nosso primeiro marco temporal. Na jovem República, as disposições normativas revelavam a hanseníase como um "problema de saúde pública", mas havia certa ambigüidade nas classificações e prescrições legais. A enfermidade não constou como doença de notificação compulsória desde cedo, em vista das dificuldades do diagnóstico clínico precoce, isto é, da verificação da doença em sua fase inicial. Como se sabe, a enfermidade apresenta características fisiopatológicas cujas expressões clínicas enredavam os médicos daquele tempo, a saber: a) uma parte dos indivíduos tem resistência imunológica ao agente etiológico e outros não, daí derivando modalidades de apresentação clínica e repercussões médico-sanitárias distintas; b) por essas razões, durante séculos "leproso" era não só o indivíduo hoje considerado "hanseniano", mas todos os casos clínicos em que se revelassem manifestações cutâneas ao longo da evolução de uma enfermidade.

A segregação de todos tinha implicações perversas: enfermos com hanseníase passavam a conviver com indivíduos porta- dores de outras enfermidades, os quais, ao cabo e ao fim, adquiriam a hanseníase e vice-versa.

A favor da hipótese da dificuldade de diagnóstico clínico apontam os termos utilizados ao se introduzir a lepra como doença de notificação compulsória ("lepra ulcerada"), que constam das Instruções para o Serviço de Higiene de Defesa da Capital da República, de 18/09/1902, e que regulamentavam o Decreto $n^{\circ}$. 4.464, de 12/07/1902, na gestão do médico Nuno de Andrade. $\mathrm{O}$ instrumento normativo acrescentava, então, a enfermidade "ulcerada" à notificação obrigatória da varíola, difteria, tifo, febre tifóide, tuberculose "aberta" e das chamadas enfermidades "pestilenciais" (febre amarela, peste e cólera, como regra) (BRASIL, 1902). Mais tarde, sob a inspiração de Oswaldo Cruz, que assumira a Diretoria Geral de Saúde Pública, em 23 de março de 1903, o Código Sanitário dava "novo Regulamento aos Serviços Sanitários a cargo da União", por meio do Decreto n. 5.156, de 8 de março de 1904 (BRASIL, 1904). As disposições mantinham a lepra no elenco de doenças de notificação compulsória, mas acrescentavam algumas outras, entre elas o impaludismo e infecções de caráter nosocomial, como a infecção puerperal nas maternidades. Note-se que não se tratava, apenas, da "defesa sanitária" da capital da República; agora eram incluídos os serviços sanitários a cargo da União, que abrangiam a defesa de todos os portos nacionais - por certo, normas com pouca eficácia fora do Rio de Janeiro e das principais capitais do país.

A criação do Departamento Nacional de Saúde Pública (DNSP), em janeiro de 1920, tendo à frente Carlos Chagas, reforçava os rumos de crescente ação pública na área de saúde, com a adoção dos programas de profilaxia rural em vários estados de responsabilidade federal, a disseminação de postos e centros de saúde urbanos e a superação de uma visão emergencial ou localizada. A presença crescente do Estado Nacional nas políticas de saúde culminou, nos anos 40, já em pleno Estado Novo, na criação ou reorganização de vários serviços nacionais, entre os quais, a programação 
de um Serviço Nacional da Lepra. Este período, ao demarcar o início de um efetivo processo de ordenamento burocrático do setor de combate à hanseníase, representa o segundo marco temporal, que encerra o presente estudo.

\section{Tempos de institucionalização}

Os tempos do cientista e sanitarista Carlos Chagas marcaram a suplantação das doutrinas e práticas de "polícia" sanitária. Todavia, era inevitável que espaços de ação médico-policial se mantivessem em relação a moléstias para as quais o próprio conhecimento sobre a disseminação era escasso e controvertido. Era este, seguramente, o caso da lepra, objeto de atenção das autoridades sanitárias - ou talvez mesmo de alerta máximo -, diante da pandemia que grassava em vários estados. O sistema adotado baseava-se em três elementos: notificação obrigatória; exame periódico dos comunicantes; e isolamento em colônias agrícolas, asilos, hospitais ou no próprio domicílio do doente. $\mathrm{O}$ isolamento no domicílio era aceito pela autoridade sanitária, desde que não oferecesse grandes riscos de contágio. $\mathrm{O}$ doente e seus familiares eram, no entanto, mantidos sob rigorosa vigilância e submetiam-se a exames periódicos.

A notificação compulsória da hanseníase foi reafirmada, em 1923, pelo Decreto $n$. 16.300, de 31 de dezembro, artigo 445, inciso X, do Regulamento do Departamento Nacional de Saúde Pública. Essa legislação tornava obrigatória a notificação de outras doenças, além do mal de Hansen, tais como febre amarela, peste, cólera, tifo, varíola, alastrim, tuberculose, tracoma, leishmaniose e impaludismo. O artigo 446 do Regulamento especificava:

Incumbe fazer a notificação: a) ao médico assistente ou conferente, e, em sua falta, ao chefe da família ou parente mais próximo que residir com o doente ou suspeito, ao enfermeiro ou pessoa que o acompanhe; b) nas casas de habitação coletiva, aos que as dirigirem ou por elas responderem, ainda que a notificação já tenha sido feita pelo médico, ou outra pessoa; c) ao que tiver a seu cargo a direção de estabelecimento comercial, industrial ou agrícola, colégio, escola, asilo, casa de saúde ou hospital, creche, maternidade, dispensário, policlínica ou estabelecimentos congêneres onde estiver o doente ou suspeito. Nos casos de lepra a notificação incumbe também ao próprio doente.

Os artigos 447 e 448 previam punições severas para médicos que não cumprissem as disposições contidas no artigo precedente. De acordo com o artigo 447, o médico que infringisse as disposições seria declarado suspeito pelo Departamento Nacional de Saúde Pública, sendo todos os doentes por ele visitados sujeitos à verificação por parte da autoridade sanitária. $\mathrm{O}$ artigo 448 previa multa de $100 \$$ a $500 \$$, dobrada nas reincidências, aos que deixassem de fazer as notificações exigidas pelo regulamento (BRASIL, 1923).

Era freqüente, até as primeiras décadas do Brasil republicano, o cenário de famílias inteiras de leprosos, como ciganos errantes por estradas e cidades, sobrevivendo ao descaso das autoridades sanitárias diante da exclusão e do estigma. As questões da nacionalidade, às quais se associavam o "problema da raça" e o "melhoramento eugênico", passaram a demandar a eliminação da mancha da hanseníase no Brasil republicano. Após o descaso sobreveio a punição institucional: além do estigma, os doentes ressurgiram então como corpos policiados, vítimas de políticas de institucionalização quase sempre cruéis. "Asilar" era, no entanto, um verbo que abrigava certa polissemia. A crueldade não era uma constante. As colônias agrícolas, em alguns estados, revelavam uma concepção de organização social de "vida em comunidade" que, para muitos internos, seria impossível no mundo que a própria medicina ajudara a transfigurar, reforçando as concepções do normal e do patológico. No Brasil, alguns estados destacavam-se nas estatísticas de casos mórbidos (São Paulo e Minas Gerais, no Sudeste, e os estados da Amazônia); um deles - o Maranhão - cedo ocupou a atenção de sanitaristas, pesquisadores e autoridades da saúde.

Em meados da década de 20, havia uma pandemia de hanseníase não só no Maranhão, mas em vários estados brasileiros. 
As estatísticas da época, por certo estimativas grosseiras e subestimadas, apontavam aproximadamente $15 \mathrm{mil}$ hansenianos em todo o país, sendo $90 \%$ pobres ou miseráveis. São Paulo, possivelmente com menor proporção de casos não-notificados, apresentava 4.500 leprosos, Minas Gerais cerca de 500; no Norte, o Pará listava 2.500 notificações, Amazonas registrava 800 e o Maranhão, cerca de 600 (MAGALHÃES; ROJAS, 2005). Como se verá adiante, medidas sanitárias foram adotadas, pelos governos federal e estaduais, tais como: criação de preventórios para as crianças que hoje se chamariam "de risco"; isolamento compulsório dos doentes em leprosários (classificados em colônia agrícola, hospital, asilo e sanatório) ou no próprio domicilio; notificação obrigatória, já referida; e exame periódico dos comunicantes (SILVA ARAÚJO, 1927, p. 195-253).

A hanseníase gerou uma preocupação pela saúde pública e se tornou uma área importante da atuação do Estado. Em virtude do forte impacto público da doença, ou, por outra, por sua dramaticidade e pelo indesejado "conteúdo simbólico", academias de medicina e centros de pesquisa engajaram-se no debate sobre as medidas necessárias de prevenção e controle. A hanseníase, assim, somava-se à ancilostomíase, à febre amarela, à tuberculose e à malária, como uma ameaça a mais à civilização, à raça e à nação (CASTRO SANTOS, 1985, p. 193-209; LIMA; HOCHMAN, 1996, p. 23-40; HOCHMAN, 1998).

Todavia, não constituía uma ameaça, digamos, "brasileira", pois incomodava as elites e as autoridades sanitárias em toda a América Latina. Trinta anos depois das "pandemias" brasileiras, a tomada de consciência sanitária em relação à lepra se disseminou por todo o continente. Diários de motocicleta, filme dirigido por Walter Salles, inspirado nos diários do jovem Ernesto Guevara, durante sua primeira viagem pela América Latina, mostra como a lepra era estigmatizada em toda parte e como era forte a defesa do isolamento compulsório pelo saber médico da época. Prestes a se formar em Medicina, Guevara decide cruzar a América Latina, ao lado do amigo bioquímico Alberto Granado. Uma cena importante de Diários de motocicleta se passa num leprosário, em San Pablo, na Amazônia peruana, em junho de 1952. Após quase duas semanas na colônia, Che descreve os momentos da despedida:

Um grupo de pacientes da colônia veio até a sede, para uma festa de despedida para nós dois. [...] Diversos deles nos deram adeus com lágrimas nos olhos. Seu apreço veio do fato de que nós não usamos sobretudos ou luvas, de que apertamos suas mãos [...], sentamos ao seu lado, conversamos sobre assuntos variados e jogamos futebol com eles. [...] O benefício psicológico de essas pobres pessoas [...] serem vistas como seres humanos normais é incalculável, e o risco de ser contaminado, incrivelmente remoto (GUEVARA, 2001, p.160 e 166).

A colônia rural, habitada pelas vítimas da hanseníase, pode ser vista como símbolo da segregação na América Latina. Obregón mostra que, na Colômbia, até início dos anos 50 , nenhuma doença foi tão estigmatizada. A imagem da hanseníase estava profundamente arraigada à cultura colombiana. Mas não era o único problema de saúde que as autoridades sanitárias teriam que enfrentar no país. Como no Brasil, a ancilostomíase, a sífilis, a tuberculose e a malária também acometiam com grande violência as populações pobres. Segundo a autora, as autoridades colombianas traçaram uma estratégia geral de saúde pública, de tal modo que o combate à hanseníase passou a fazer parte de um plano mais amplo de saneamento. Essas doenças eram consideradas um retrato de um país enfermo e um entrave ao processo de modernização do país. Também como tantas outras doenças infecciosas, acreditava-se que a hanseníase havia penetrado no país com a imigração européia e com os negros africanos. As autoridades médicas procuravam seguir um plano geral de controle e preconizavam a destinação de recursos não somente para campanhas de combate à lepra, mas também à ancilostomíase, à malária e à tuberculose (OBREGÓN, 1996 e 2003).

$\mathrm{O}$ isolamento compulsório dividia a opinião médica. Para muitos, era ineficaz como método de prevenção e tratamento. No Brasil, desde os tempos da monarquia, 
eram abundantes os relatórios e documentos que ilustravam a situação deplorável a qual estavam submetidos os doentes nos hospitais, leprosários e dispensários, em vários estados brasileiros. Como no Hospital de Lázaros, em São Cristóvão, na capital federal, médicos descreviam as péssimas instalações, o sofrimento dos pacientes, os tratamentos ineficazes (SANTOS, 2003, p. 419). Desde 1828, neste hospital, denunciavam-se os maus tratos aos pacientes (SANTOS, 2003, p. 416). Em São Paulo, as péssimas condições do Hospital dos Lázaros levavam o presidente da província, já no Segundo Reinado, a conclamar: "fechai aquele sepulcro ou abri as portas de um hospital regular, indo em auxílio da caridosa irmandade [...] que o tem a seu cargo" (EGAS, 1926, p. 302). Na Santa Casa de Misericórdia de São João Del Rei, entre 1879 e 1880, as instalações destinadas aos lázaros "se localizavam no fundo do quintal da instituição" (SANTOS, 2003, p. 416). No decorrer do período republicano, ao mesmo tempo em que se firmavam as propostas da corrente segregacionista, as instâncias de práticas institucionais disciplinares e inumanas se multiplicavam em vários estados, como se verá na discussão do "modelo" paulista, mais à frente.

Mas havia os que defendiam o aprimoramento e humanização desse tipo de prática, em instituições isoladas do mundo urbano; havia os que postulavam a construção de modernos hospitais para leprosos em áreas urbanas e escolas para crianças portadoras. Pesquisas epidemiológicas e bacteriológicas enfatizavam a importância dos vários tratamentos para diversos tipos da doença. Mesmo quando se propunha o controle da hanseníase através da segregação, defendia-se a necessidade de novas terapias.

De todo modo, não foram tranqüilos os caminhos percorridos em busca de alternativas de tratamento para uma doença caracterizada por forte estigma e preconceitos (OBREGÓN, 1996, p.159-178). De maneira geral, a medicina latino-americana debatia a enfermidade em seus aspectos sociais (ainda que não focalizasse seus determinantes); da mesma forma, caracteri- zava como "enfermidades sociais" a sífilis, a loucura, a tuberculose, cujas conseqüências mais evidentes eram e degeneração física e moral do indivíduo. Neste sentido, médicos e higienistas passaram a utilizar argumentos científicos da época - dosados por fortes conotações raciais -, diante dos comportamentos e hábitos da população pobre latino-americana. Essas enfermidades sociais, de certo modo mais ainda do que as populações pobres, representavam grandes entraves à modernização.

No período estudado, o empenho de médicos, sanitaristas e higienistas no combate às enfermidades sociais, entre as quais se destacava a lepra, mostra a construção de uma concepção de atenção à saúde, que ficou conhecida como "higienista". Esta proposta tornou-se importante nos países da América Latina, apontando para iniciativas públicas na área social. Mais do que isto, o debate em torno de questões como raça, miscigenação e cultura gerou um ambiente propício a alguns movimentos reformistas. A saúde passou a ser vista como uma questão nacional, com desafios que os movimentos de mudança procuraram enfrentar (FARIA; PAIVA, 2007, p. 203-218).

\section{Como a doença se manifesta?}

Retomemos alguns aspectos sublinhados na introdução. Doença infectocontagiosa de notificação compulsória, a hanseníase também é conhecida como morféia, tem caráter crônico e afeta a humanidade desde eras remotas. O contágio é relativamente difícil, pelo contato íntimo e prolongado com pessoas infectadas - pelas vias aéreas ou pelo contato direto com ferimentos. O maior número de casos encontrase nos países tropicais e subtropicais - Índia (75\% dos casos mundiais), Nepal, Brasil, Sudão, Moçambique, Madagascar e Angola. Segundo Magalhães e Rojas, na atualidade não resta dúvida de que a distribuição da lepra está mais concentrada nesses países e associa-se fortemente a condições sociais e higiênico-sanitárias desfavoráveis. Nas palavras das autoras, "a relação entre pobreza e lepra ratifica o papel da deterioração social em sua produção, não obstante em alguns 
países considerados hiperendêmicos, estudos detalhados em áreas muito pobres terem encontrado prevalências muito baixas, o que sugere a existência de condições que não propiciaram a entrada ou sobrevivência do agente patogênico" (MAGALHÃES; ROJAS, 2005, p. 2-3). Tudo indica que a existência de fatores de ordem biológica ou de fatores não diretamente "sociais" deve ser considerada e estudada.

A doença atinge a pele e o sistema nervoso periférico, apresentando duas formas principais: a hanseníase cutânea e a hanseníase nervosa. A primeira é menos grave, com manchas na pele e progressiva perda de sensibilidade cutânea. $\mathrm{Na}$ outra forma, conhecida como lepromatosa, aparecem nódulos, os nervos se transformam em cordões nodosos e sobrevêm fortes dores, insensibilidade e deformidade. Finalmente, o bacilo ataca os tecidos, consumindo as mãos, os pés, o nariz, os olhos. O período de incubação é, em geral, prolongado - de dois a cinco anos entre o contágio e o aparecimento dos primeiros sintomas. Manchas cutâneas de diferentes tipos e em pontos diversos do organismo, insensíveis ao calor, constituem um sinal da infecção (CRM-SP, 2006).

Eidt (2004, p. 77) sustenta uma posição polêmica: "se o Mycobacterium leprae acometesse somente a pele, a hanseníase não teria a importância que tem em saúde pública”. Do ponto de vista antropológico, a existência de preconceitos de "marca", em sociedades latino-americanas, dificilmente corroboraria tal afirmação, tomada de modo absoluto. No entanto, é inegável que a constituição da enfermidade como problema de saúde pública deveu-se também ao acometimento do sistema nervoso periférico, de modo a se traduzir em incapacidades físicas permanentes (EIDT, 2004, p. 76-88).

$\mathrm{Na}$ forma cutânea, o bacilo se multiplica de maneira rápida. A mão em forma de garra é assinalada nas descrições da patologia, assim como as lesões ósseas e articulares, as mutilações pela destruição e a perda de parte ou totalidade dos dedos. São freqüentes, ainda, a úlcera da sola do pé e a atrofia dos músculos da face. Na hanseníase nervosa, os nervos são atacados, sendo muito importante para o diagnóstico a nevrite cubital, que acomete pessoas com alta resistência ao bacilo; as lesões são poucas, com ausência de sensibilidade.

$\mathrm{Na}$ história da hanseníase era comum entre os portadores acreditarem que haviam contraído a doença apenas quando esta se manifestava na sua forma cutânea, mais adiantada, "que transforma, que transfigura, que aniquila a fisionomia individual. Freqüentemente, diz um estudioso, a população nega e descrê da moléstia quando se manifesta sob a forma nervosa" (MENDONÇA, 1923, p. 19).

\section{A atuação do Departamento Nacional de Saúde Pública e a criação de uma legislação sanitária}

Desde 1920, o Departamento Nacional de Saúde Pública, no âmbito do Ministério da Justiça e Negócios Interiores, abrigava uma Inspetoria de Profilaxia da Lepra, das Doenças Venéreas e do Câncer, primeiro órgão federal destinado à campanha contra a hanseníase no país. Era uma peça-chave da reforma institucional empreendida por Chagas. A Inspetoria nos estados atuava por meio da antiga Diretoria de Saneamento Rural, em cooperação com os governos estaduais. As atribuições do novo Departamento permitiram que várias regiões mais pobres pudessem contar com apoio federal para evitar a expansão da doença. Ainda que marcado por limitações institucionais e financeiras, o DNSP sinalizava uma "inflexão" nas ações da esfera pública, pois, até então, nenhuma ação de governo fora tomada para combater a difusão da hanseníase no território nacional. Existiam, na capital e em alguns estados, hospitais para leprosos, mantidos por associações privadas ou pelos governos estaduais, mas não havia uma legislação sanitária visando a profilaxia da doença. No Distrito Federal, os serviços eram diretamente executados pela Inspetoria. Nos estados, dada a organização política do país, a execução era feita mediante acordo com os respectivos governos, que, segundo Oscar da Silva Araújo (inspetor de Profilaxia da Lepra e das Doenças Venéreas), "deveriam respeitar 
e fazer cumprir, dentro de seu território, a legislação sanitária federal" (SILVA ARAÚJO, 1927, p. 196).

Em função do alto custo para detecção e tratamento dos doentes, a hanseníase assumiu uma feição de política "federal", uma questão de saúde pública diante da qual o poder central deveria organizar uma estrutura de prevenção e tratamento. A Reforma Carlos Chagas incluía entre suas propostas: estabelecimento de estatísticas mais precisas sobre os óbitos de lepra; providências sanitárias nos domicílios onde houvesse óbito por lepra; criação de leprosários e dispensários; e organização de campanhas de educação sanitária (BRASIL, 1923).

\section{O Regulamento Sanitário - Legislação Sanitária}

O Regulamento Sanitário teve origem na Legislação Federal que criou o Departamento Nacional de Saúde Pública, em setembro de 1920. Foi o sifilógrafo Eduardo Rabelo, nomeado diretor geral da nova Inspetoria de Profilaxia da Lepra e das Doenças Venéreas, quem elaborou a primeira legislação brasileira que tratava especificamente dessas enfermidades (CARRARA, 1996). No exame da evolução histórica da legislação, feito anteriormente, já nos referimos às disposições normativas sobre aquelas doenças.

Um estudo pioneiro, no Brasil, indicava o mérito da reforma Carlos Chagas, por abranger parcelas cada vez maiores da população, mas, ao mesmo tempo, sustentava que se tratava de uma política autoritária. Esse autoritarismo, na verdade, dizia respeito às disposições sobre o controle da lepra contidas no Regulamento elaborado por Eduardo Rabelo, que facultava a requisição de força policial para obrigar os suspeitos ao exame eao isolamento compulsório (SINGER; CAMPOS; OLIVEIRA, 1978). No entanto, a análise histórica, a nosso ver, não deveria negligenciar o estágio rudimentar do conhecimento científico sobre a moléstia naquele momento. Não era outra a política nem eram outras as limitações, fora do Brasil.

O Regulamento prescrevia, em resumo, as seguintes medidas relativas à moléstia: a) notificação obrigatória; b) levantamento do censo de leprosos; c) isolamento obrigatório em domicílio, colônias agrícolas, sanatórios, hospitais ou asilos; d) vigilância sanitária dos doentes isolados em domicílio; e) vigilância sanitária dos suspeitos; f) vigilância sanitária preventiva dos comunicantes; g) assistência pecuniária aos leprosos isolados ou às suas famílias; h) proibição do exercício, por leprosos, de ofícios ou profissões [...] perigosos à coletividade; i) proibição da entrada no território nacional de estrangeiros leprosos; j) proibição da amamentação natural pelas mulheres leprosas; $[\ldots] ; \mathrm{m}$ ) segregação imediata dos filhos nascidos de pais leprosos; [...]; q) educação higiênica popular no sentido de tornar conhecidas as condições de contágio da doença (SILVA ARAÚJO, 1927, p. 198-199).

\section{Primeiras ações institucionais}

As primeiras colônias agrícolas foram instaladas nas áreas dos grandes focos ao norte e ao sul do país. No Estado do Pará, em 1923, segundo o sifilógrafo Oscar da Silva Araújo - ou em junho de 1924, segundo estudo recente -, foi inaugurada a primeira colônia agrícola para leprosos no Brasil, chamada Lazarópolis do Prata, a $150 \mathrm{~km}$ da capital (SILVA ARAÚJO, 1927, p. 206; SANTOS, 2003, p. 425). Nesta mesma época, foi iniciada a construção de um hospital de isolamento no Maranhão, com verbas previstas pelo governo federal. Mas, durante anos, a obra ficou paralisada em virtude da falta dos recursos federais (SILVA ARAÚJO, 1927, p. 195-253).

A capital federal não foi a primeira a acolher os doentes em "leprosarias" porque as autoridades temiam, segundo Oscar da Silva Araújo (1927, p. 207), que houvesse uma demanda incontida por parte dos estados vizinhos, com hospitalização inadequada. Não obstante, afirmava o estudioso, "ainda hoje [em 1927] se verifica que 50\% dos doentes existentes no Distrito Federal, [no Hospital dos Lázaros e no Hospital São Sebastião], não são aqui domiciliados" (SILVA ARAÚJO, 1927, p. 207). Não haveria como retardar a iniciativa por muito tempo: em 1928 foi inaugurado o Hospital Colônia de Curupaiti, no bairro de Jacarepaguá (SANTOS, 2003, p. 423). O DNSP planejou a construção de uma grande colônia agrícola no Pará e duas outras em Minas Gerais. Em 
São Paulo, o próprio governo estadual já vinha providenciando a construção de uma colônia em Santo Ângelo.

No início de suas atividades, o DNSP firmou acordo com 18 estados, com exceção de São Paulo, para trabalhos de saneamento rural e de combate à lepra e doenças venéreas. Ocupava a Presidência da República Artur Bernardes. As diretrizes de seu governo, no tocante à organização da saúde pública, se explicitaram em mensagem apresentada ao Congresso Nacional, em 03 de maio de 1923.

Os serviços sanitários, entre nós, foram organizados sob o critério fundamental de centralização, a fim de atender a condições especiais do País, concernentes à difusão e intensidade das endemias rurais e à deficiente capacidade técnica ou financeira de algumas unidades da federação, sem meios para assumirem a responsabilidade integral do saneamento de seus territórios (BERNARDES, 1923).

À União cabia administrar, organizar e financiar metade das despesas dos serviços de profilaxia rural e de programas de educação nos estados brasileiros. Além da profilaxia das doenças rurais, cabia à União a responsabilidade pela assistência hospitalar às pessoas infectadas pelas endemias.

As primeiras medidas sanitárias incluíram: realização de censos em todos os estados; registro dos doentes; estabelecimento de um regime de vigilância sanitária para os leprosos que permanecessem em domicílio; aplicação do óleo de chalmugra (na época a planta era conhecida como chaulmoogra); e construção de colônias agrícolas (SILVA ARAÚJO, 1927). Naquele momento, o tratamento era o recurso mais empregado na campanha anti-hanseniana. Para o DNSP, o tratamento se combinava à profilaxia preventiva, pois esta visava evitar a reclusão ou o isolamento obrigatório. $\mathrm{O}$ tratamento precoce evitaria tanto a progressão da doença quanto o contágio.

Além do desempenho de funções previstas no Regulamento da Legislação Sanitária, a Inspetoria de Profilaxia da Lepra e das Doenças Venéreas já constituía um importante centro de estudos e pesquisas, em cujos laboratórios buscavam-se criar medicamentos destinados ao tratamento da doença. Em 1923, a Inspetoria criou o Serviço de Visitadoras. Um curso intensivo de seis meses sobre doenças venéreas e lepra foi organizado para formação e orientação de um grupo de senhoras, que posteriormente foram substituídas por enfermeiras regularmente diplomadas. As visitadoras ficaram encarregadas de levar à população carente noções e conceitos de higiene (SILVA ARAÚJO, 1927, p.211; BARROS BARRETO, 1942, p.169-215).

A propagação da moléstia levou o Departamento Nacional de Saúde Pública a realizar, na capital do país, a Primeira Conferência Americana da Lepra, em 1922, de cuja organização ficou encarregada a Inspetoria. Participaram delegados de quase todos os países americanos e de alguns países europeus. Essa Conferência significava uma nova área de atuação e, sobretudo, de estímulo ao intercâmbio e ao associativismo profissional na América Latina e em outros continentes. A Conferência reuniu médicos, sanitaristas, intelectuais e autoridades sanitárias, para debaterem as estatísticas e os modos de diagnóstico e prognóstico da doença.

O debate sobre a qualidade das estatísticas, como já referido, era um elemento crucial para as políticas sanitárias, dada a inexistência de dados seguros sobre a trajetória da hanseníase em inúmeros estados brasileiros. Os arquivos de higiene traziam ligeiras referências sobre a penetração da enfermidade, sua expansão e o número de pessoas afetadas (MENDONÇA, 1923).

Como já salientado, não raro se associa a figura de Carlos Chagas à preferência por medidas impositivas, voltadas à exclusão e reclusão dos hansenianos. A nosso ver, este é um julgamento cediço. Na reforma de Chagas, a preocupação com a prevenção e a educação foi um aspecto fundamental. $O$ Regulamento do DNSP, de 31 de dezembro de 1923, enfatizava a importância de uma campanha de propaganda e educação higiênica e o tratamento profilático dos doentes em dispensários ou hospitais. Nos artigos 108 e 109 do Regulamento especificavam-se as normas de divulgação da propaganda sanitária. Ao Serviço de Propaganda e Educação Sanitária competia promover ampla divulgação das noções de 
higiene pessoal e pública. O Serviço ficaria encarregado da organização de folhetos e cartazes e da publicação de um pequeno jornal ilustrado, destinado à educação popular. Caberia ainda a publicação periódica de um ou mais boletins destinados a divulgar, entre os médicos e profissionais de saúde publica, os recentes progressos da cultura sanitária especializada. O artigo 173 do Regulamento indicava a extensão das atribuições que cabiam à Inspetoria:

a Inspetoria de Profilaxia da Lepra promoverá larga propaganda de educação higiênica popular no sentido de tornar conhecidas as condições de contágio da doença, o perigo do charlatanismo médico e farmacêutico a ela referentes e os meios de prevenção aconselhados (BRASIL, 1923).

Segundo Sérgio Carrara (1996, p. 218-220), a base da profilaxia proposta pelo Regulamento Sanitário assentava-se sobre dois pilares: uma ampla campanha de propaganda e educação higiênica (individual e coletiva) e o tratamento profilático dos doentes (o mais generalizado possível) em dispensários e hospitais especializados. Ou seja, visava, de um lado, impedir o contágio através do diagnóstico precoce e tratamento do doente e, de outro, proteger os indivíduos sadios, esclarecendo-os quanto aos modos de transmissão conhecidos na época e alertando-os para os primeiros sintomas ou sinais. Daí a ênfase na junção da propaganda à educação higiênica. $\mathrm{O}$ controle dos graves problemas sanitários exigia a ação educativa e a adoção, pela população, de medidas preventivas de cuidado com o corpo e com o meio ambiente (FARIA, 2007).

$\mathrm{Na}$ área da profilaxia, a educação sanitária e a propaganda higiênica, conduzidas nos dispensários, leprosários, asilos e hospitais por meio de cartazes, folhetos e artigos nos jornais e exposições, foram instrumentos poderosos. $O$ combate não apenas à hanseníase, mas também às doenças venéreas, ao câncer e à sífilis incluía aspectos de educação sanitária.

A proposta de prevenção pela educação popular sofreu forte influência dos padrões e métodos de trabalho dos higienistas norte-americanos, que se difundiram no
Brasil no mesmo tempo de sua expansão por alguns países do continente europeu. $\mathrm{Na}$ França, desde 1917, os pesquisadores e sanitaristas da Fundação Rockefeller estabeleceram parcerias para a operação do Comité National de Défense contre la Tuberculose (MURARD; ZYLBERMAN, 1987, p. 257-281). Sob este ângulo, a atuação da Fundação Rockefeller no Brasil foi emblemática. Ainda que não tivesse atuado no campo da hanseníase, ao aqui chegar, em 1916, a Fundação Rockefeller reforçou, no país, uma concepção de saúde pública baseada na profilaxia de doenças infecciosas e estimulou novos padrões de educação sanitária e de formação de profissionais de saúde pública (FARIA, 2007).

\section{O "exemplo paulista" e uma política maranhense de profilaxia}

As discussões em torno de uma política profilática centrada na exclusão compulsória dos portadores da hanseníase eram antigas. A Primeira Conferência Internacional da Lepra, ocorrida em Berlim, em 1897, foi palco dessas lutas, no que diz respeito tanto à produção de conhecimentos sobre a doença quanto ao direcionamento das políticas de saúde que possibilitaram a implantação, em alguns países, de uma política baseada na segregação. Numa época em que não havia medicamentos realmente eficazes e não se conheciam com segurança os modos de transmissão da doença, Hansen propôs o isolamento como medida necessária. Para os partidários desse esquema segregacionista, o combate à lepra só seria possível através do isolamento dos leprosos em suas colônias (PANDYA, 2003, p. 161-177; MACIEL, 2004, p. 110).

No Brasil, dadas as discordâncias quanto aos melhores meios de ação, não é de se estranhar que até a década de 20, quando foi criado o DNSP, as iniciativas relativas ao combate à hanseníase e às doenças venéreas tenham sido incipientes e raras. São Paulo representava uma referência neste aspecto. Para Monteiro (1987, p.1-7; 2003, p.95-121), as políticas de saúde implantadas no Brasil, no início do século $X X$, no tocante à doença de Hansen, foram 
fortemente influenciadas pelo "modelo" adotado em São Paulo, que previa, entre outros pontos, o isolamento compulsório de todos os portadores de hanseníase em colônias agrícolas. Mesmo aqueles que não possuíam a forma contagiosa da doença eram obrigados ao internamento. Segundo a autora, "o que nós chamamos de 'modelo paulista' serviu como fonte de inspiração e, em maior ou menor extensão, determinou uma política de profilaxia para a doença em vários estados brasileiros" (MONTEIRO, 2003, p.97). Enquanto o isolamento era uma prática alternativa em alguns estados brasileiros - alternativa essa defendida por uma parte dos médicos presentes nos congressos nacionais e internacionais sobre lepra-, em São Paulo era uma medida compulsória para todos os indivíduos diagnosticados com a doença.

É importante frisar que na Primeira Conferência Americana da Lepra, reunida em outubro de 1922, no Rio de Janeiro, foram firmadas algumas medidas de defesa ou de proteção aos leprosos que não visavam o isolamento compulsório em colônias. Segundo Maciel (2004, p. 116), "São Paulo e Minas Gerais eram dos poucos estados que aplicavam a política de isolamento compulsório com rigor, inclusive com casos de denúncia, como forma de controlar a doença".

Do ponto de vista das redes de relações sociais, as autoridades pareciam não temer dissolvê-las ou fragilizá-las, quando exigiam o internamento de um doente. Não se dava importância, segundo a autora, à manutenção dos laços familiares. O impacto, ao longo de toda uma vida, sobre a autoestima dos internados e a criação de uma ou mais gerações de estigmatizados não se colocavam como desafios importantes de saúde pública. A história dramática de um hanseniano, nascido em Minas Gerais e internado aos 16 anos, em 1934, é reproduzida, de modo exemplar, a partir de depoimento colhido em 2002 (MACIEL, 2004). O objetivo da internação e do isolamento compulsórios era evitar a propagação da doença a qualquer custo.

Por outro lado, não há como negar o recurso a procedimentos menos desumanos, por muitos defensores de colônias agríco- las; falava-se em cotidiano saudável, em ambiente campestre, em certa comunhão solidária entre os internados. Do sul ao norte, prevalecia uma proposta de pequena comunidade urbano-rural, para os hospitaiscolônias de confinamento. A exemplo do Hospital Colônia de Itapuã, em Viamão, fundado em 1940, no Rio Grande do Sul, os internos, envolvidos na estrutura administrativa das colônias, assumiam funções que dificilmente eles poderiam ocupar entre os "normais" (MUSEU DE HISTÓRIA DA MEDICINA DO RIO GRANDE DO SUL, 2007). A visão do médico maranhense Sálvio de Mendonça, que será apresentada mais adiante, ilustra bem essa postura até certo ponto idílica, sobre a organização social das colônias e a vida autônoma dos internos.

Em São Paulo, a defesa do isolamento gerou conflitos e discussões científicas, institucionais e profissionais. Segundo seu contemporâneo Vital Brazil, Emílio Ribas, à frente do Serviço Sanitário paulista, conseguiu "impulsionar o movimento social em favor dos leprosos" (VITAL BRAZIL, 1933, p. 5). Ribas defendia o isolamento dos leprosos, mas era exigente quanto à boa organização e administração dos leprosários e dispensários. Em um de seus trabalhos, assim escrevia: "acho indispensável o isolamento; sou de parecer que essa medida só deve ser executada, depois de feitas instalações realmente capazes de oferecer conforto, higiene e cuidados médicos". (RIBAS apud MOURA, 1993, p. 1).

Quando Geraldo Horácio de Paula Souza - sanitarista e diretor do antigo Instituto de Higiene de São Paulo - assumiu a direção do Serviço Sanitário, em 1922, propôs uma reformulação dos serviços de saúde. Entre outras providências, criou, no estado, a Inspetoria de Profilaxia da Lepra. Seu primeiro diretor, José Maria Gomes, avesso, como Paula Souza, ao isolamento hospitalar, traçou um programa de tratamento ambulatorial da doença. Na época, foi criticado por suas idéias. Paula Souza bateu-se pela revogação do art. 654 do Código Sanitário paulista, que tornava compulsório o isolamento do doente de lepra quer em domicílio, quer em hospital (MASCARENHAS, 1973, p. 446; CAMPOS, 2002, p. 105-106; FARIA, 2007, p. 60,86). 
Havia dissensões, como se disse. Em 1931, Francisco de Salles Gomes Jr. - médico e especialista em hanseníase, do grupo opositor a Paula Souza - assumiu a direção do Serviço Sanitário. Do ponto de vista operacional, aponta Yara Nogueira Monteiro (1987, p. 1-7), São Paulo concentrou nas mãos do diretor do Serviço Sanitário e do Serviço de Profilaxia da Lepra amplos poderes de decisão e definição de políticas e programas. Ao ocupar o cargo, Salles Gomes procurou imprimir outros rumos à organização dos serviços de combate à lepra. O formato institucional preponderante buscava verticalizar as ações sanitárias, separadamente por doença.

Assim, os serviços específicos seriam "o modelo" ou padrão típico de organização sanitária, que acompanhariam, no plano estadual, os rumos da atenção federal aos serviços da lepra, tuberculose e malária (FARIA, 2007). Salles Gomes era um fervoroso defensor do isolamento compulsório. Houve medidas de segregação não apenas para a lepra, mas também para tuberculose e doenças venéreas, durante toda a década de 30 (MONTEIRO, 1987, p.1-7; 2003).

As décadas de 40 e 50 trariam novos rumos: com o avanço dos medicamentos quimio-terápicos, as sulfonas, o controle da doença deixou de ser realizado, em grande medida, pelo isolamento e segregação dos doentes (AVELLEIRA; NERY, 1998, p. 2-3; EIDT, 2004, p.76-88; MACIEL, 2004). Ressurgiam, então, as propostas de tratamento nos ambulatórios, como pregavam Paula Souza e José Maria Gomes.

É possível dizer, com base em relatórios e trabalhos científicos publicados no Maranhão no início do século $\mathrm{XX}$, que as autoridades sanitárias daquele estado tentaram seguir o caminho adotado por São Paulo, mas com menos rigor em relação aos doentes que supostamente apresentassem a forma contagiosa da doença. A questão do isolamento compulsório era discutida entre médicos e autoridades maranhenses. Os relatórios do diretor do Serviço de Saneamento e Profilaxia Rural no Maranhão, dr. Cássio Miranda; do chefe do Serviço de Profilaxia da Lepra e das Doenças Venéreas, dr. Sálvio Mendonça; do chefe do Posto de Cururupu, dr. Attico Seabra; do dr. Heitor Pinto, chefe do Posto de Profilaxia de Caxias; do dr. Hamleto Godóis, chefe do Posto da capital, defendiam, de modo geral, a construção urgente de leprosários para confinamento dos doentes, o que evitaria, segundo pensavam, a difusão da doença pelo estado.

Mas mesmo a política de institucionalização não atendia aos apelos do corpo médico. Diferentemente de São Paulo, o Maranhão não possuía serviços sanitários ou assistência médica e hospitalar sistemáticos e eficazes. No tocante ao atendimento aos leprosos, o Hospital dos Lázaros de Gavião, na capital, a cargo da Santa Casa, funcionava apenas como um lugar de recolhimento. Não havia tratamento ou medicamentos necessários. Em 1923 sobre esse local escrevia o médico Sálvio Mendonça (1923, p. 248; 253):

\begin{abstract}
As medidas de profilaxia ainda não podem ser rigorosas sobre esses doentes, pela razão de não haver leprosário para recolhimento dos doentes ambulantes. O leproso mendigo e esfarrapado não se recolhe ao Hospital dos Lázaros, verdadeiro cemitério de vidas, porque esse hospital não lhes oferece conforto, nem mesmo lhes facilita a entrada, pois não existe lotação para isso, e esse mesmo doente não pode ser obrigado ao isolamento domiciliário, porque nem casa tem para o fazer. [...] Os leprosos do estado fogem desse hospital, aterrados pelas suas tradições e mesmo pelo seu estado atual.
\end{abstract}

Já em São Paulo, durante toda a década de 30 , foram construídas várias colônias para leprosos, com apoio também de particulares (MONTEIRO, 2003, p.95-121). É importante chamar a atenção para o fato de que, em São Paulo, o número de casos registrados, em parte devido à melhor qualidade da produção de estatísticas, era considerado alarmante no início dos anos 20 e continuou a crescer durante a década de 30. Essas condições por certo suscitavam o autoritarismo do governo paulista.

\section{A hanseníase no Maranhão: o drama na periferia da nação}

Historicamente, quanto mais nos afastamos dos tempos atuais, menos confiáveis 
são as estatísticas epidemiológicas. São, portanto, sempre sujeitos à revisão os dados disponíveis para a pesquisa historiográfica. Magalhães e Rojas (2005) indicam que, no final do século XIX, teriam sido registrados 1.640 casos de lepra no país. Se considerarmos esses dados, os estados do Maranhão, Pará e Amazonas concentravam 14\% dos casos totais, com uma população, na época, de $6 \%$ em relação aos outros estados brasileiros. Chamam a atenção, segundo as autoras, os dados estatísticos de 1926, que apontam para um quadro agravante para aquela região. Neste ano, aqueles estados concentravam $13 \%$ dos casos totais de lepra, mas representavam agora apenas $1 \%$ da população brasileira.

Até a criação do DNSP, não havia, a rigor, uma política federal para os estados, com exceção dos serviços de profilaxia rural. Nos primeiros anos da década de 20 , seriam cerca de mil os hansenianos no Maranhão. A maioria dos municípios não tinha condições de cuidar efetivamente dos problemas da saúde pública; basicamente, só havia serviços sistemáticos e regulares na capital do estado e em alguns municípios atendidos pelos postos do Serviço de Saneamento e Profilaxia Rural. O perigo de alastramento da doença de Lázaro mobilizou as autoridades sanitárias e políticos na busca de soluções. O estudo da história pregressa e da distribuição geográfica da hanseníase no Maranhão, nas primeiras décadas do século XX, era falho. Segundo Sálvio de Mendonça (1923, p. 8), delegado maranhense na Conferência Americana da Lepra, "não nos coube saber de quando apareceu a moléstia no Maranhão, de quando começa ali a sua invasão [...] degradante, no espetáculo funambulesco de suas mutilações".

Apesar da carência de informações precisas sobre o número de doentes e a extensão da propagação da doença, o médico Sálvio de Mendonça fornece alguns dados referentes a municípios maranhenses. Segundo ele, em 1923, o contingente de leprosos no estado, em torno de mil pessoas, era registrado em função da procura aos dispensários. Naquela época, apenas onze municípios haviam sido recenseados, mas cinco focos principais podiam ser detectados, áreas "de grande freqüência e grande propagação" (MENDONÇA, 1923, p.251-252): São Luiz, com 189 leprosos recenseados (em uma população total de 60 mil); Anajatuba, com 87 doentes em uma população de 10 mil habitantes, "sendo o mais intenso foco"; Viana, com 94 doentes e 23.000 habitantes; Macapá, com 41 leprosos e 7.000 habitantes, "o maior centro de lepra na zona do Recôncavo"; e Caxias com 48 doentes, com uma população aproximada de 50.000 habitantes (AZEVEDO, 1951, p. 27). Para o total de municípios recenseados, havia 501 leprosos, sendo 329 homens e 172 mulheres. Deste total, $58 \%$ dos casos eram da forma nervosa, $16 \%$ da forma cutânea e $25 \%$ da forma mista (MENDONÇA, 1923, p. 4-5).

No início do século XX, as baixadas dos Rios Mearim e Pindaré e o recôncavo de uma pequena parte da costa e do vale do Rio Itapecuru eram considerados verdadeiros focos de contágio. "Porque aí foram os primeiros pontos da imigração (sic) negra", afirmava um estudioso em 1923, "o fato é que a lepra acompanha a trilha dos rios e das costas" (MENDONÇA, 1925, p. 251). Essas regiões, maiores centros de agricultura e lavoura do Maranhão, com pequenos núcleos de habitações rurais, praticamente não possuíam serviços de higiene ou assistência médica e hospitalar. Na região do Rio Mearim tomou a moléstia grandes proporções, em localidades como Viana, Matinha, Penalva, Monção e São Luiz Gonzaga. Nessa região, em que viviam quase 20 mil pessoas, foram recenseados cerca de 150 hansenianos.

Um dos focos mais ativos da moléstia, que se disseminava por todo o Maranhão, era representado pela terra natal de Nina Rodrigues - Anajatuba. "É um lugarejo sórdido pela sua localização, por suas condições telúricas, por seus meios de comunicação, por suas condições de vida e de trabalho" (MENDONÇA, 1923, p.12). A migração interna, de maranhenses e nordestinos, contribuía para o alastramento da doença, com maior ou menor intensidade. Caxias e São Luiz eram importantes centros regionais afetados pela enfermidade. Em 1922, o discurso de Sálvio de Mendonça, na Confe- 
rência Americana da Lepra, assim como de outros delegados, alertava as autoridades sanitárias para a necessidade de uma profilaxia sistematizada de controle da doença. Um dos estudiosos da história da medicina no Maranhão sentenciava: o péssimo estado de salubridade do Maranhão dava, mesmo à sua capital, uma má fama, de cidade suja e insalubre (MEIRELES, 1993).

As estatísticas e relatórios sobre a região, na época, apontavam uma situação lastimável, sendo a precariedade das condições de saúde um dos traços mais adversos. Os delegados da Conferência Americana da Lepra já conheciam os resultados de um levantamento realizado em 1919 e 1920 pela Junta Sanitária Internacional da Fundação Rockefeller, com a colaboração de médicos e autoridades brasileiros. Foi justamente um especialista maranhense e delegado na citada conferência, o dr. Ático Seabra, o coordenador do health survey promovido pela Rockefeller e que detectou, além do "problema alarmante" da lepra em muitas regiões do estado, as taxas mais altas de prevalência da ancilostomíase de todo o país. O levantamento denunciava, ainda, a difusão da malária, em sua forma mais perniciosa, por todo o interior. A peste bubônica tomara de assalto a capital ainda no início da centúria, mas havia sido debelada; no entanto, por ocasião do levantamento sanitário, havia um surto de febre amarela e a varíola se tornara endêmica (FUNDAÇÃO ROCKEFELLER, 1919-1920; MEIRELES, 1993, p. 55).

\section{As primeiras medidas profiláticas. A terapêutica}

A impossibilidade de a maioria dos estados enfrentar os problemas de saúde, sem o apoio material e financeiro do governo federal, contribuiu para que este interferisse de forma direta apenas nos momentos de surgimento ou recrudescimento de crises epidêmicas, abrindo caminho, por outro lado, para o estabelecimento de parcerias tanto estaduais como federal - com a agência filantrópica de atuação mais expressiva na época, no setor da saúde pública, que era a Fundação Rockefeller. Acordos foram firmados entre a Rockefeller e os governos dos estados do Rio de Janeiro, São Paulo e Minas Gerais, além do Distrito Federal. O Maranhão foi o único estado nordestino a receber auxílio da Fundação, antes de 1920, que orçou em pouco mais de 16 mil dólares, em valores correntes da época. No entanto, como já salientado anteriormente, as condições complexas de controle da lepra, enfermidade endêmica cuja sintomatologia, profilaxia e tratamento não eram conhecidos com segurança, desestimulavam os investimentos federais ou a cooperação internacional. A verba destinada pela Rockefeller ao Maranhão foi direcionada, basicamente, para estudos e campanhas de prevenção da malária, que incluíam o levantamento sanitário realizado em todo o estado, entre 1919 e 1920, coordenado pelo dr. Ático Seabra, especialista em lepra (CASTRO SANTOS; FARIA, 2003).

Desde os primeiros tempos republicanos, existia naquele estado um débil movimento favorável à criação e organização de serviços de saúde. Um Serviço Sanitário estadual reuniu as antigas "repartições" de higiene, pela Lei no. 301, de 19/04/1901. Ainda no governo de Colares Moreira (19021906), vice-governador empossado após renúncia do governador eleito, uma primeira medida legislativa foi a aprovação da Lei no. 322 , de 26 de março de 1903, que previa a construção de um hospital para leprosos. A história maranhense reserva sucessivos episódios de adiamento de medidas concretas, quando outras enfermidades se antepunham à lepra, tornando-se prioridades para a política administrativa.

Desde outubro de 1903, multiplicaramse as notificações dos casos de peste bubônica em São Luís. A epidemia provocou a interferência da Diretoria Geral de Saúde Pública, que enviou do Rio de Janeiro primeiramente um bacteriologista de Manguinhos, Henrique Marques Lisboa, e mais tarde dois outros higienistas, auxiliados por médicos vindos de São Paulo e, nas palavras de um estudioso, por "um grupo de apoio da terra" (MEIRELES, 1993, p. 67). Os trabalhos de controle da epidemia, finalmente debelada em maio de 1904, abriram caminho para a primeira reorganização 
do Serviço Sanitário (Lei no. 358, de 9 de junho de 1904), cuja direção coube a um dos integrantes da equipe médica paulista, Augusto Militão Pacheco (MEIRELES, 1993, p. 68). Nos governos seguintes, apesar de a demanda de óleos vegetais, a partir da Primeira Guerra Mundial, ter ativado a economia do babaçu no estado, sem contar certo dinamismo da produção de algodão e das fábricas de tecidos (AZEVEDO, 1951, p. 26), a saúde pública não chegou a representar uma prioridade para as sucessivas administrações.

A frágil máquina administrativa do estado só se movia diante da emergência de um surto epidêmico. Na ausência de epidemias, pouco se fazia. No governo de Luís Domingues (1910-1914), a literatura indica, como feitos relevantes, a criação de um Instituto de Assistência à Infância, de um hospital anexo (chamado Moncorvo Filho) e de um curso de Enfermagem, realizado no Instituto de Assistência e dirigido por duas enfermeiras inglesas, especializadas em obstetrícia - Margareth Laurie e Gertrudes Colet (MEIRELES, 1993, p. 65-74). Anos depois, foram a ameaça da chegada ao Maranhão da "gripe espanhola" e a ocorrência de um surto de febre amarela e de novos focos de peste bubônica que atraíram alguma atenção governamental à saúde pública.

O governador Urbano Santos, figura de expressão no jogo político nacional, ministro da Justiça do presidente Delfim Moreira (1918-1919), eleito governador para o período 1918-1922, não dispunha, no entanto, de um esquema de forças políticas coesas, no Maranhão, que sustentassem um plano de modernização. Se a ação do Estado, no plano sanitário, teve alguma expressão em seu governo, isto deveu-se à presença crescente dos aparelhos do governo central em todo o Norte, inclusive no Maranhão.

Desde 1918, mas particularmente após a criação do Departamento Nacional de Saúde Pública, em 1920, o governo maranhense foi estimulado a adotar algumas medidas no campo sanitário, pautadas nas disposições do novo órgão federal. Esse cenário foi decisivo para criação de um Serviço de Saneamento e Profilaxia Rural; pelo estabelecimento, em São Luís, ainda em 1919, de uma filial de Manguinhos, sob a direção do médico bacteriologista Cássio Miranda; e pela inauguração de um Dispensário da Lepra e Moléstias Venéreas. O Serviço de Profilaxia não conseguiu, entretanto, levar adiante o projeto de construção de um leprosário, "na margem esquerda da foz do lbacanga" (MEIRELES, 1993, p.72). As frentes de trabalho contra a lepra não atraíam, na década de 20 , a atenção que outras moléstias recebiam, por parte do governo federal.

Note-se que as comissões de Profilaxia Rural, em vários estados, são anteriores à própria criação, no Distrito Federal, do Departamento Nacional de Saúde Pública: desde abril de 1919, operava a Comissão de Profilaxia Rural no Maranhão, sob a direção do sanitarista Raul de Almeida Magalhães - um dos fundadores da Sociedade Brasileira de Higiene -, designado pelo governo federal para assumir em São Luís tanto a coordenação daquela Comissão, como a Comissão de Febre Amarela. Mais ainda, num procedimento típico da atuação federal nos rumos da saúde dos estados, MagaIhães acumulou também (de julho de 1919 a fevereiro de 1920) a chefia do Serviço de Higiene do Estado do Maranhão (MIRANDA, 1925, p.122).

A Comissão de Profilaxia da Febre Amarela foi extinta ainda em 1920, mas o governo organizou nova Comissão, para a peste bubônica, em 1921. Em outubro de 1922 registrava-se o último caso, na capital do estado (MIRANDA, 1925, p.122124). Houve alguns anos depois um surto epidêmico de varíola em várias regiões do interior e na capital, durante o governo de Godofredo Mendes Viana (1922-1926). A epidemia foi debelada após uma campanha de vacinação, conduzida pela filial do Instituto Oswaldo Cruz, em São Luís (MEIRELES, 1993, p. 65-74). Em 1923, reativou-se a campanha antiamarílica nos estados do Norte e Nordeste por uma Comissão de Febre Amarela, organizada pela Fundação Rockefeller; chegava ao Maranhão, em dezembro daquele ano, para chefiar os serviços de combate à doença, o dr. José Figuerôa, encarregado pela Fundação 
(MIRANDA,1925, p.83). Em alguns dispensários da capital, que tratavam da lepra e doenças venéreas, cadastraram-se as meretrizes para o tratamento antivenéreo, por meio do trabalho de enfermeiras visitadoras (MIRANDA, 1925, p.247). Havia, igualmente, dispensários no interior do Estado.

Não há menção ao local de formação das enfermeiras visitadoras; talvez tivessem sido treinadas nos cursos intensivos mantidos pelas inspetorias estaduais, voltadas para a profilaxia da lepra e das doenças venéreas, em conformidade com as disposições do DNSP; deve-se descartar a possibilidade de terem se originado dos primeiros núcleos de ensino da Enfermagem no Maranhão, junto ao Instituto de Assistência à Infância, em São Luís. Uma vez formadas, essas enfermeiras eram empregadas no atendimento hospitalar, particularmente na área maternal e infantil, como auxiliares de clínicos (LISBOA,1923, p. 142-143). No entanto, não se pode descartar ter havido o aproveitamento de algumas profissionais formadas pela nova Escola de Enfermeiras e Parteiras do Maranhão, criada no início de 1922 por um grupo de médicos e tendo entre seus dirigentes e professores nomes que atuavam no campo da lepra, como o médico Filogônio Lisboa. Nessa nova escola, não se privilegiava apenas o ensino de noções de cirurgia e obstetrícia. $\mathrm{O}$ projeto era formar enfermeiras hospitalares (LISBOA, 1923, p.143), mas houve diplomadas que prestaram serviços ao dispensário de lepra e doenças venéreas, anexo ao Hospital da Profilaxia, bem como a um Hospital de Doenças Rurais, aberto em 1921, nas antigas instalações do Hospital Militar em São Luís (MIRANDA, 1925, p.222).

Um elemento importante dos trabaIhos de saúde pública, as atividades da enfermagem nos dispensários de lepra e moléstias venéreas não se resumiam em aplicar injeções e curativos, estendendo-se ao que então se denominava o campo da Higiene. Data dessa época a organização de uma Associação das Enfermeiras do Maranhão, pelas enfermeiras diplomadas nos dois cursos ligados ao Instituto de Assistência à Infância e à Profilaxia Rural (LISBOA, 1923).
Durante a administração do governador Godofredo Mendes Viana, o Serviço de Saneamento e Profilaxia Rural esteve sob a chefia do médico Cássio Miranda. No decorrer de 1923, segundo Miranda, foi restabelecida a "normalidade" dos serviços de saneamento e profilaxia rural, que haviam sido afetados pelos trabalhos de combate à peste bubônica (MIRANDA, 1925, p.241). Deve-se notar, também, que o serviço da febre amarela, a cargo da Rockefeller, permitia uma troca de experiências entre profissionais que destoavam do meio cultural e científico "atrasado" da capital, lembrando a referência às futilidades de um meio atrasado, feita por Filogônio Lisboa (1923, p.141). Nesses termos, a referência à "normalidade" dos serviços, festejada por Miranda, não era de fato uma frase auspiciosa.

Sálvio de Mendonça chefiava o Serviço de Profilaxia da Lepra e das Doenças Venéreas do Maranhão, subordinado ao Serviço de Saneamento e Profilaxia Rural. Seu relatório dá conta de várias medidas, algumas novas, outras rotineiras. Foram aplicadas 2.263 injeções do óleo de chalmugra, distribuiu-se sistematicamente o preparado em gotas, foram melhoradas as condições higiênicas do Hospital dos Lázaros, aumentada a vigilância sanitária em estabelecimentos comerciais, domicílios e colônias. Foram tomadas, ainda, providências para impedir com "medidas moderadas" as profissões de alguns doentes que pudessem pôr em risco a saúde da população.

Havia um projeto de construção, pelo governo do estado, de uma leprosaria em São Luís. Aquiles Lisboa - higienista, botânico, leprólogo e eugenista, figura de destaque nos meios científicos nacionais, membro da Comissão Central Brasileira de Eugenia e mais tarde governador do Estado - chamava a atenção para a ausência, em São Luiz, de um abrigo de isolamento: "embora incompleto, primitivo mesmo, sempre pode abrigar melhor tais infelizes. A Santa Casa de Misericórdia tem [...], segundo somos informados, as suas enfermarias repletas" (LISBOA, 1928, p.37).

À frente dos serviços da lepra, Sálvio de Mendonça tinha uma postura de especialista, não a de um intelectual, ao modo 
de Aquiles: se este pontificava sobre a lepra "como o mais perigoso dos inimigos da pátria" (PORTELA NUNES, 2000, p. 293), Sálvio tinha propostas concretas: seus escritos e palestras não se limitavam a criticar um projeto de construção de um asilo-leprosário, um prédio com pavilhão que, a seu ver, só faria sentido se abrigasse um pequeno número de doentes. Em função de seu alto número, o Maranhão necessitava de uma instituição "em tipo colônia, para mil e muitos leprosos, do conforto dos campos, em vivendas familiares, no exercício de suas próprias atividades. A colônia agrícola dá independência coletiva" (MENDONÇA, 1925, p.254). Sobre o local ideal para o empreendimento:

O sítio Sá Viana, já destinado para essa leprosaria [...], presta-se magnificamente a uma colônia agrícola. Completamente isolado de São Luiz pelo rio Bacanga, formando quase que uma pequena ilha por um afluente desse rio e a Baía de São Marcos (MENDONÇA, 1923, p.19).

As atividades do Serviço de Profilaxia da Lepra, de comunicação com o público, contribuíram para aumentar a freqüência de doentes nos seis dispensários do estado, sobretudo no Dispensário Central, dirigido pelo médico Filogônio Lisboa, e no dispensário da Santa Casa de Misericórdia, chefiado pelo médico Antonio Vieira de Azevedo. Note-se que esses estabelecimentos eram, também, dedicados à chamada profilaxia "antivenérea", não se limitando aos portadores do "mal-de-lázaro". Nos dispensários de Caxias e Viana funcionava um serviço de assistência aos leprosos, sob a orientação do chefe do posto de profilaxia rural, com um enfermeiro e uma enfermeira para atendimento aos doentes (MIRANDA, 1925, p.79-84).

Os médicos Heitor Pinto e Ângelo Leite eram, respectivamente, os inspetores-chefes dos postos rurais, agregando as funções de chefia dos dispensários e dos postos. No relatório de Heitor Pinto, evidencia-se a precisão das informações de caráter histórico e censitário (realizou-se um recenseamento dos leprosos na região), bem como a atenção à literatura sanitária estrangeira. Dela se extraem ensinamentos para a profilaxia dos doentes maranhenses: "nos lazaretos da ilhas Filipinas e de Havaí, [...] domina a preocupação do alimento sadio, dos exercícios físicos, do asseio corporal, do cuidado para que não ocorram infecções secundárias nas lesões" (PINTO, 1925, p.272). Como chefe do posto rural em Caxias, a postura de Heitor Pinto em relação às verminoses e, em especial, a ancilostomíase destoa da visão até certo ponto otimista sobre o serviço da lepra.

São quase insuperáveis as dificuldades que se encontram para a consecução [...] das providências profiláticas [...] de proteção do homem contra a infestação [...] e de proteção do solo contra a contaminação. [...] Essa infestação entre gente que nunca faz uso do calçado é contínua, é diária, é habitual; enquanto que a medicação é rara e espaçada. Nesse círculo vicioso, vence a endemia (PINTO, 1925, p.198).

Em contraposição, a atitude é de alento diante do "movimento altruístico e dignificante" da população de Caxias, para dotar a cidade de um abrigo para assistência aos leprosos e para o trabalho de profilaxia (PINTO, 1925, p. 273).

\section{O Maranhão no início do período getulista}

Os primeiros anos da Revolução de 30 foram marcados, no Maranhão, pela instabilidade política e paralisia administrativa, por força da indicação federal de governos provisórios, chefiados por interventores sem respaldo na política regional. A literatura destaca a eleição, pela Assembléia Constituinte de 1935, do "sábio" Aquiles Lisboa (MEIRELES, 1993, p. 77; COSTA FILHO, 1964 p.13-18), que por ser "isento de paixões políticas" teria obtido o apoio consensual. Na verdade, justamente a falta de laços políticos fortes, fosse com a União Republicana Maranhense, fosse com o Partido Republicano, tornou-o incapaz de proceder à indicação de cargos e prebendas sem enfrentar oposições, que acabaram por the mover um impeachment em junho de 1936 (MEIRELES, 1993, p. 77; PORTELA NUNES, 2000, p. 240). Aquiles Lisboa foi sucedido por Paulo Martins de Souza Ramos, com bom trânsito entre as facções estaduais 
dos "peerristas" e "unionistas". Governou até o início do Estado Novo; escolhido por Vargas, permaneceu como interventor federal durante oito anos (1937-1945).

O novo governo consolidou as ações de saúde no espírito das propostas de João de Barros Barreto, no Distrito Federal. Foi aberto um Centro de Saúde na capital e novos postos de saúde espalharam-se pelo interior, que se somavam aos que existiam desde a Primeira República. No Centro de Saúde, em São Luís, passou a funcionar a Diretoria Geral de Saúde Pública estadual. O Hospital de Doenças Rurais foi denominado de Hospital Geral do Estado. Foram abertos hospitais para alguns dos chamados "flagelos sociais" da época, como a tuberculose, as doenças mentais e, com atenção especial, a lepra (MEIRELES, 1993, p. 78; PORTELA NUNES, 2000, p. 240). Em outubro de 1937 fundou-se a colônia-hospital do Leprosário do Bonfim, localizada em "local paradisíaco" da Praia da Guia, na ponta do Bonfim, totalmente isolada da cidade. A Colônia do Bonfim chamou-se, mais tarde, Aquiles Lisboa, médico considerado por muitos o pioneiro do tratamento da hanseníase no Maranhão (PINHO, 2007, p.4).

$\mathrm{Na}$ verdade, os progressos conquistados no governo Paulo Ramos, que permitiram à Santa Casa de Misericórdia reduzir ou compartir suas responsabilidades no tocante ao isolamento e cuidado dos leprosos, doentes mentais e tuberculosos, deviam-se em larga medida ao amadurecimento do debate sanitário no próprio estado, isto é, a certa massa crítica constituída desde os anos 20 não somente no estado, mas em todo o Norte e Nordeste do país. A Conferência Americana da Lepra e os Congressos Brasileiros de Higiene, já mencionados, foram um exemplo dessa efervescência do debate, em especial sobre a hanseníase. Nessa medida, parece-nos discutível que a literatura destaque o "pioneirismo" de Aquiles Lisboa; mais pertinente seria a referência a um grupo pioneiro, no qual militavam também Sálvio de Mendonça, Heitor Pinto, Filogônio Lisboa e Ático Seabra, entre outros. Meireles faz um balanço do período:

na administração de Paulo Martins de Souza Ramos [...] só em São Luiz o Estado mantinha nada menos que nove órgãos - um centro de saúde, um pronto-socorro, um hospital geral, um hospital infantil, três outros hospitais especializados, uma maternidade e um isolamento, enquanto pelo interior se espalhavam postos de saúde nas principais cidades (MEIRELES, 1993, p.78-79).

No entanto, as iniciativas, por certo tardias, não impediram o aumento de casos de lepra no Maranhão. No final dos anos 30 e início da década seguinte, eram cerca de 1.800 doentes de Hansen, uma freqüência de um por mil habitantes. Praticamente dobrou o número de portadores no estado (RAMOS, 1940). Em parte, deve-se assinalar que o melhor preparo na "melindrosa tarefa" de recensear os doentes, tarefa assumida em Caxias, em censo cuidadoso, pelos próprios médicos do Posto Rural (PINTO, 1925, p.197; 367), provavelmente resultou nas estatísticas mais elevadas não só naquele município, mas em todo o estado, pondo a nu uma realidade que jazia parcialmente encoberta. Nas palavras do médico Heitor Pinto (1925, p. 367): pondo os recenseadores "na pista de vários outros casos até então ignorados".

\section{Os anos 40 e o Serviço Nacional da Lepra}

Nos anos 40, os processos de centralização política e administrativa se aceleraram sob o comando-maior de Vargas, no interior do Ministério Capanema, entre 1934 e 1945 (PAIVA, 2004). Nessa medida, os contornos das políticas de saúde nos estados do Norte se conformavam, progressivamente, à legislação e à política sanitária geradas na Capital da República. A legislação federal sobre lepra era, então, a que constava no Regulamento do antigo Departamento Nacional de Saúde Pública, aprovado pelo Decreto n. 16.300 de 1923, conhecido como reforma Carlos Chagas. Posteriormente, fizeram-se modificações importantes na organização da saúde pública federal, não havendo, entretanto, na parte referente à regula-mentação da lepra, atualização legislativa substancial. Mas em alguns estados foram decretados novos regulamentos sobre a lepra, sendo uns incluídos nas reformas dos departamentos estaduais de saúde e outros elaborados especificamente para o mal de Hansen. 
Com a reorganização do Departamento Nacional de Saúde, em 1941, foi criado o Serviço Nacional da Lepra. Neste ano, Gustavo Capanema, ministro da Saúde do Governo Vargas, propôs alterações na estrutura do Ministério, procurando, segundo Hochman e Fonseca (2000, p. 180), "tornar mais centralizada a atuação dos órgãos federais de saúde nos estados e criando para tanto os serviços nacionais de saúde". Vários serviços foram organizados para combate não apenas à lepra, mas também à tuberculose, à febre amarela, à malária, ao câncer e à peste. Nessa década, quando a leprologia cada vez mais se institucionalizava como especialidade, iniciou-se uma política nacional de controle da doença no país. A criação dos Serviços Nacionais ampliou substancialmente a esfera de ação e autoridade do governo federal, dando maiores poderes para intervir nos estados. A partir desse momento, todos os serviços de higiene, de saneamento e de profilaxia rural dos estados estavam sob o controle efetivo do governo federal.

Ao Serviço Nacional da Lepra caberia coordenar o plano de combate em todo o país, constituindo-se, portanto, em centro orientador, coordenador e fiscalizador das atividades dos serviços públicos e privados de prevenção, diagnóstico precoce e assistência médica; a ele cabia também realizar estudos e inquéritos sobre a doença; selecionar os casos para isolamento institucional ou domiciliar; fiscalizar o tratamento no dispensário dos doentes não contagiantes; exercer a vigilância sanitária assídua dos doentes isolados em domicílio e das crianças internadas em preventórios; e, finalmente, recambiar os doentes procedentes de outros distritos sanitários que viessem a residir na área de ação dos centros de saúde, sem a permissão das autoridades sanitárias (BRASIL, 1944, p. 83-85). Neste ponto devemos remeter os leitores às considerações realizadas anteriormente, sobre o autoritarismo das disposições legais, desde a reforma Carlos Chagas. Não resta dúvida de que os rudimentos de conhecimento científico sobre a hanseníase, naqueles tempos, abriam pouco espaço à superação das práticas de confinamento adotadas em todo o mundo.
Não obstante, houve uma atenção genuína à formação de recursos humanos para a prevenção e controle, além da ênfase na educação sanitária. O Serviço Nacional da Lepra tornou-se responsável pela formação de técnicos especializados. A prevenção por meio da educação higiênica representou a pedra de toque das políticas públicas. Nesse particular, aqui como em outros países, a importância da educação sanitária era enfatizada pelas missões internacionais da Fundação Rockefeller. Wilson George Smillie, membro do International Health Board da Fundação Rockefeller e parceiro do jovem parasitologista Samuel Pessoa, na Faculdade de Medicina de São Paulo, desde a década de 20 já afirmava que "um programa de educação sanitária requer a cooperação da população e só obterá sucesso se tiver a aprovação total da comunidade" (FUNDAÇÃO ROCKEFELLER, 1919). O objetivo era incentivar também, por meio da propaganda, a prática de exames periódicos, de caráter preventivo.

Apesar da criação dos serviços de saúde e da maior participação federal nos trabalhos de profilaxia rural, ainda eram falhos os dados sobre a distribuição geográfica da hanseníase no país. O próprio Serviço Nacional da Lepra, em relatório sobre a situação da doença no Brasil, dizia ser difícil "apresentar dados numéricos reais", em virtude de não haverem sido recenseados todos os municípios brasileiros. Desde 1940, o Serviço Nacional da Lepra vinha organizando um censo, com as fichas de leprosos e comunicantes. Tal tarefa contava com o apoio dos Serviços Estaduais de Profilaxia da Lepra (AGRÍCOLA, 1943).

O censo, prática já adotada nos serviços de profilaxia antes de 1930, foi uma das primeiras medidas do Serviço Nacional da Lepra. Conhecidos os doentes, localizados e classificados, do ponto de vista clínico e profilático, dar-se-ia início às medidas para solução dos casos, por meio do isolamento dos casos contagiantes, além de indigentes e mutilados, "não só por constituírem espetáculo repulsivo e antiestético, como também, um dever sob o ponto de vista da assistência social" (AGRíCOLA, 1944, p.7). Como se vê, ainda que a visão oficial ado- 
tasse o ponto de vista da assistência social, nos moldes franceses e anglo-saxônicos, o estigma ou a repulsa, lá como cá, caminhavam juntos.

O Maranhão constituía uma das poucas exceções, com boa qualidade das estatísticas. Também era o caso do Distrito Federal e dos estados do Rio Grande do Norte, Alagoas, Espírito Santo, Rio de Janeiro e São Paulo, que tiveram seus municípios totalmente recenseados; mas os estados restantes careciam de dados completos. No estado do Amazonas - uma das áreas mais afetadas pela lepra - somente seis, dos 28 municípios, haviam sido recenseados, em 1942. O Ceará, outro exemplo de altos índices da doença, possuía 52 municípios sem censo, num total de 79 . As diferenças nos dados coletados eram bastante significativas entre os estados de maior índice de contaminação: São Paulo, 21.270; Minas Gerais, 10.227; Pará, 4.931; Amazonas, 2.127; Paraná, 1.747; Ceará, 1.403; Maranhão, 1.267; Goiás, 1.154. Dentro de cada região, não se encontrava, tampouco, um padrão uniforme. Se, nas regiões hoje conhecidas como Norte e Meio Norte, o número de doentes fichados até 1942 era elevado, havia uma exceção, que era o Piauí. No Nordeste, ante a situação aparentemente favorável de estados como a Bahia e o Rio Grande do Norte, eram elevadas as estatísticas para Ceará e Pernambuco. No CentroOeste, Goiás tinha o triplo de doentes do Mato Grosso. No Sul, o Paraná apresentava um número mais elevado de doentes do que o Rio Grande do Sul e Santa Catarina, nesta ordem. Se havia alguma uniformidade, esta era a de um padrão alto de ocorrências no Sudeste, não fosse o caso excepcional elevadíssimo - de São Paulo (AGRÍCOLA, 1943, p. 78).

O número de leprosários e o de doentes internados também variavam de estado para estado. Em 1942, São Paulo possuía o maior número de unidades: Pirapitinguí, com 2.371 internos; Padre Bento, com 891, Aimorés, com 1.272 internos, Santo Ângelo, com 1.779 e Cocais, com 1.854 internações. Minas Gerais, Pará e Goiás tinham três leprosários cada um, Amazonas e Ceará possuíam dois leprosários e Maranhão, Pernam- buco, Espírito Santo, Paraná e Rio Grande do Sul, um leprosário. No Leprosário de Bonfim, no Maranhão, havia 193 internados, em 1942. A atuação do Serviço Nacional da Lepra nos estados era um fator determinante para prevenir situações de abandono ou negligência, como ocorria no Amazonas. Um relatório do médico João Batista Risi, enviado pelo serviço federal a Manaus, em agosto de 1942, para inspeção das colônias do Aleixo e Paricatuba, encontrou os enfermos "em situação de verdadeiro degredo", com precário atendimento médico e total isolamento de Manaus (AGRíCOLA, 1943, p.65). Outra era a situação, por exemplo, em São Luís do Maranhão, onde o Serviço de Profilaxia estadual contava com dois médicos para a Colônia e Dispensário, ambos com curso de lepra, ou na Colônia gaúcha de Itapuã, com um médico-chefe residente (AGRÍCOLA, 1943, p.78).

O número de preventórios também variava de um estado para o outro: Minas Gerais possuía três unidades; São Paulo e Espírito Santos tinham dois cada um e os outros estados contavam com um preventório para assistência às crianças, filhos dos hansenianos. No Maranhão, o Educandário Santo Antonio, mantido pela Sociedade de Assistência aos Lázaros e Defesa Contra a Lepra, abrigava 13 crianças. Os preventórios eram vistos, a partir do (des)conhecimento científico da época, como uma parte importante do programa de profilaxia. Para o Serviço Nacional da Lepra, o afastamento das crianças do convívio com os pais, ou dos parentes portadores da doença, seria uma forma de assegurar o controle da doença em médio prazo. O nome geralmente dado a essas instituições, de "educandário", tornava manifesto o intuito dos poderes públicos de assistir ou educar aquelas crianças; em um dos casos, em Minas Gerais, o preventório buscava explicitamente o "aprendizado técnicoprofissional” para os internos (AGRÍCOLA, 1943, p. 62).

Em 1943, havia em todo o país 36 leprosários, compreendendo colônias agrícolas ou hospitais-colônias, hospitais e asilos, além de 50 dispensários distribuídos por alguns estados. Em 1943, Minas 
Gerais ultrapassou São Paulo em número de leprosários. Além das colônias de Santa Izabel e Santa Fé e do Hospital de Sabará, foram construídos a Colônia São Francisco de Assis, a Colônia Padre Damião e o Sanatório Roça Grande. Vários estados, no entanto, não tinham meios, ou lhes faltava o arcabouço político necessário, que os colocassem em sintonia com a política nacional; continuavam carentes de hospitais, sanatórios, asilos, colônias, dispensários e preventórios. Para os médicos e sanitaristas do Serviço Nacional da Lepra, era flagrante o contraste entre os estados, no tocante àquelas instituições.

Leprosários, dispensários e preventórios. Esse foi o tripé sobre o qual se sustentou a atuação do Serviço Nacional da Lepra na profilaxia do mal de Hansen em todo o país. Para Ernani Agrícola (1944, p. 6), inspetor dos Centros de Saúde do Estado de Minas Gerais e mais tarde diretor do Serviço Nacional da Lepra, "estas peças, perfeitamente organizadas, com funcionamento adequado e em número suficiente, garantem um melhor e mais proveitoso trabalho para dominar a expansão da lepra, sua redução e posterior desaparecimento como problema sanitário". Considerando deficiente o número de leprosários, dispensários e preventórios, o Serviço Nacional da Lepra incluiu em seu programa de ação para os anos subseqüentes um plano de instalações dessas unidades, principalmente nas zonas onde a incidência da doença era alta. Os dispensários eram responsáveis pelo controle de cerca de $60 \%$ do total de doentes fichados e, além da assistência clínica e terapêutica aos doentes não isolados em leprosários, realizavam a vigilância sanitária, a descoberta de novos casos e a educação sanitária nos focos (BRASIL, 1946).

Em 1946 o Serviço Nacional da Lepra construiu, concluiu ou ampliou estabelecimentos naqueles estados em que mais intensa se apresentava a endemia. Todas as unidades da Federação passaram a contar com um ou mais leprosários, funcionando regularmente e destinados a isolar os doentes contagiantes. É importante ressaltar que, em São Paulo, a construção destas unidades ocorreu sem auxílio federal. A experiência paulista, tanto na questão da lepra como na luta contra outras enfermidades ou flagelos, tinha uma face dupla, de independência em relação à política federal, mas também de influência sobre essa própria política. A política de isolamento, a implantação de vários serviços específicos e a construção de colônias agrícolas foi o caminho encontrado pelas autoridades sanitárias estaduais para conter a doença e tentar eliminá-la (MONTEIRO, 2003, p.100102). Não era diferente o cenário em outros centros regionais do país.

\section{Errantes e reclusos: faces da segregação}

No Brasil, o flagelo da hanseníase data dos tempos coloniais. No início do Brasil Império efetuaram-se os primeiros recenseamentos precários, que indicavam serem "numerosos" os portadores do mal, das Minas Gerais ao Mato Grosso, de São Paulo ao Espírito Santo, de Pernambuco ao Maranhão e ao Pará, perambulantes ou confinados nos poucos lazaretos existentes (SANTOS FILHO, 1991, p.229).

Se a doença havia penetrado no país, como se pensava, pela vinda dos escravos para as fazendas, o estigma era inevitável, pois às deformações "medonhas" acrescia a marca infamante da origem escrava. Há uma ironia fortuita no fato de que, para superação da condição de errantes, segregados da sociedade, as instituições do lazareto e da colônia agrícola, da Primeira República à era getulista, impuseram-Ihes outra forma de segregação, ainda que em busca de tratamento e cura e com o fito de prevenir a propagação da moléstia.

Desde meados da década de 20 , as inspetorias e serviços de profilaxia da lepra enfrentavam a doença como um problema sanitário complexo, cuja solução exigia um conjunto de medidas e órgãos especializados em níveis distintos de intervenção: o leprosário ou colônia; o dispensário; o preventório. A história dessa moléstia, da intervenção médica e de seus atores estigmatizados envolveu um trabalho intenso de educação sanitária e da tentativa, quase 
sempre inócua, mas generosamente buscada pelas autoridades sanitárias desde o primeiro período republicano, de redução do estigma e de controle da doença.

Como o presente texto procurou indicar, os estados de São Paulo e do Maranhão representaram experiências tipicamente brasileiras. São Paulo desfrutava da presença privilegiada de recursos humanos, institucionais e financeiros. No caso maranhense, em que pesem os revezes mais fortes que sofreu e as deficiências de seus recursos durante

\section{Referências bibliográficas}

AGRíCOLA, E. Curso de leprologia no Departamento Nacional de Saúde do Ministério da Educação e Saúde. Revista do Serviço Nacional da Lepra, p. 45-82, mar. 1944

Situação da lepra no Brasil [Trecho do relatório do Dr. Ernani Agrícola, diretor do Serviço Nacional da Lepra]. Revista do Serviço Nacional da Lepra, p. 47-85, jun. 1943.

AVELLEIRA, J. C. R.; NERY, J. A. O tratamento da hanseníase. Rio Dermatológico, Rio de Janeiro, 2(3), p. 2-3, 1998.

AZEVEDO, A. de. Através do Vale do Itapecuru (Impressões de uma viagem de reconhecimento). Separata do Boletim n.120. São Paulo: Faculdade de Filosofia, Ciências e Letras da Universidade de São Paulo, p. 41, 1951.

BARROS BARRETO, J. de. A organização da saúde pública no Brasil. Arquivos de Higiene, Rio de Janeiro, 12 (2), p.169-215, 1942.

BERNARDES, A. Mensagem apresentada ao Congresso Nacional, em 3 de maio de 1923. Brasília: Câmara dos Deputados, 1978. Disponível em: <http://www.senado.gov.br/ sf/legislação>. Acesso em: 29 ago. 2007.

BRASIL. Decreto Federal n 4.464 de 12 de julho de 1902. Estabelece as Bases para a Regulamentação dos Serviços de Higiene de Defesa da Capital Federal. Coleção de Leis do Brasil. Disponível em: < http://www. senado.gov.br/sf/legislação>. Acesso em: 30 ago. 2007. toda a primeira metade do século XX, o estado venceu desafios e superou dilemas no campo da saúde, por força da atuação decisiva de seus sanitaristas e agentes de saúde. Por outro lado, não foram poucos, no Maranhão como em todo o Brasil, os insucessos e limitações dos programas governamentais no tocante à efetiva assistência e solidariedade aos estigmatizados e doentes da lepra. Do norte ao sul do país, essa história ficaria, para sempre, marcada pelo sofrimento social e individual de milhares de hansenianos.

\section{Decreto Federal $n^{\circ} 5.156$ de} 08 de março de 1904. Código Sanitário, Regulamento dos Serviços Sanitários a cargo da União, da Diretoria Geral de Saúde Pública. Coleção de Leis do Brasil. Disponível em: < http://www.senado.gov.br/sf/legislação>. Acesso em: 30 ago. 2007.

. Decreto Federal $n^{\circ} 16.300$ de 31 de dezembro de 1923. Regulamento do Departamento Nacional de Saúde Pública. Coleção de Leis do Brasil. Disponível em: <http://www.senado.gov.br/sf/legislação>. Acesso em: 30 ago. 2007.

. Ministério da Educação e Saúde. Serviço Nacional da Lepra. Regimento do Serviço Nacional da Lepra [Decreto $n^{\circ}$. 15.484, de 8 de maio de 1944]. Revista do Serviço Nacional da Lepra, p. 35-56, jun. 1944.

. Ministério da Educação e Saúde. Serviço Nacional da Lepra. Atividades do SNL - Seção de Organização e Controle. O problema dos dispensários na campanha contra a lepra. Revista do Serviço Nacional da Lepra, p. 44-65, dez. 1946.

CAMPOS, C. de. São Paulo pela lente da higiene. As propostas de Geraldo de Paula Souza para a cidade (1925-1945). São Carlos: RiMa Editora, 2002.

CARRARA, S. Tributo a Vênus: a luta contra a sífilis no Brasil, da passagem do século aos anos 40. Rio de Janeiro: Editora Fiocruz, 1996.

CASTRO SANTOS, L. A. O pensamento sanitarista na Primeira República: uma 
ideologia de construção da nacionalidade. Dados (Revista de Ciências Sociais), Rio de Janeiro, 28 (2), p.193-209, 1985.

CASTRO SANTOS, L. A.; FARIA, L. A reforma sanitária no Brasil: ecos da Primeira República. São Paulo: Editora Universitária São Francisco, 2003.

CONSELHO REGIONAL DE MEDICINA DO ESTADO DE SÃO PAULO. O êxodo invertido [edital]. Revista Ser Médico, São Paulo, n. 34, ano IX, p.10-15, jan.-fev.-mar. 2006.

COSTA FILHO, O. Maranhão. História. Enciclopédia Barsa. Rio de Janeiro, vol. 9, 1964, p. 13-18.

EGAS, E. Galeria dos presidentes de S. Paulo - período monárquico: 1822-1889. São Paulo: Publicação Oficial do Estado de São Paulo, v. 1, 1926,

EIDT, L. M. Breve história da hanseníase: sua expansão do mundo para as Américas, o Brasil e o Rio Grande do Sul e sua trajetória na saúde pública brasileira. Saúde e Sociedade, São Paulo, 13(2), p.76-88, 2004.

FARIA, L.; PAIVA, C. H. A. Saúde e doença na América Latina e no Caribe: perspectivas histórico-sociológicas. Physis (Revista de Saúde), Rio de Janeiro, 17(1), p. 203-218, 2007.

FARIA, L. Saúde e política: a Fundação Rockefeller e seus parceiros em São Paulo. Rio de Janeiro: Editora Fiocruz, 2007.

FUNDAÇÃO ROCKEFELLER. International health board. Annual Report, Rockefeller Archive Center, Pocantico Hills, N.Y, Estados Unidos, 1919.

International health board, 1919-

1920. Health Survey for Maranhão [dr. Áttico Seabra, coordenador]. Record Group 5, Subseries $305 \mathrm{IHB}$, Box 25. Rockefeller Archive Center, Pocantico Hills, NY, Estados Unidos.

GUEVARA, E. C. De moto pela América do Sul - diário de viagem. Tradução de Diego Ambrosini. São Paulo: Sá Editora. 2001.

HOCHMAN, G. A era do saneamento: as bases da política de saúde pública no Brasil. São Paulo: Hucitec/Anpocs, 1998.
HOCHMAN, G.; FONSECA, C. A I Conferência Nacional de Saúde: reformas, políticas e saúde pública no Estado Novo. In: GOMES, A. de C. (Org.). Capanema: o ministro e seu ministério. Rio de Janeiro: Editora FGV, 2000, p. 173-193.

LIMA, N. T.; HOCHMAN, G. Condenado pela raça, absolvido pela medicina: o Brasil descoberto pelo movimento sanitarista da Primeira República. In: MAIO, M. C.; SANTOS, R. V. (Eds.). Raça, ciência e sociedade. Rio de Janeiro: Fiocruz/CCBB, 1996, p. 23-40.

LISBOA, A. A lepra sob o ponto de vista da hereditariedade mórbida. [Conferência feita em 12 de julho de 1928 no Teatro da Paz]. Belém: Oficinas Gráficas do Instituto Lauro Sodré, 1928.

LISBOA, F. Organização do serviço de enfermeiras no Maranhão. Memória apresentada ao Primeiro Congresso Brasileiro de Higiene. Maranhão, 1923.

MACIEL, L. R. A solução de um mal que é um flagelo. Notas históricas sobre a hanseníase no Brasil do século XIX. In: NASCIMENTO, D. R. do; CARVALHO, D. M. (Orgs.). Uma história brasileira das doenças. Brasília: Editora Paralelo 15, 2004, p. 109-125.

MASCARENHAS, R. dos S. História da saúde pública no Estado de São Paulo. Revista de Saúde Pública, São Paulo, 7, p. 433-446, 1973.

MAGALHÃES, M. da C. C.; ROJAS, L. M. Evolución de la endemia de la lepra en Brasil. Revista Brasileira de Epidemiologia, Rio de Janeiro, 8 (4), p. 342-355, 2005.

MEIRELES, M. Apontamentos para a história da medicina no Maranhão. São Luís: Sioge, 1993.

MENDONÇA, S. A lepra no Maranhão. In: CONFERÊNCIA AMERICANA DA LEPRA. Anais... Maranhão: Livraria Soares, 1923.

MENDONÇA, S. Serviço de Profilaxia da Lepra e das Doenças Venéreas. In: MIRANDA, C. (Org.). Os trabalhos de saneamento rural no Maranhão em 1923. 
Maranhão: Tipogravura Teixeira, 1925, p. 245-263.

MIRANDA, C. Os trabalhos de saneamento rural no Maranhão em 1923. Maranhão: Tipogravura Teixeira, 1925.

MONTEIRO, Y. N. Hanseníase: história e poder no Estado de São Paulo. Hansenologia Internationalis, 12 (1), p.1-7, 1987.

Prophylaxis and exclusion: compulsory isolation of Hansen's disease patients in São Paulo. História, Ciências, Saúde - Manguinhos, Rio de Janeiro, 10, suplemento I, p. 95-121, 2003.

MOURA, J. V. de C. Emílio Marcondes Ribas. São Paulo: Sociedade Brasileira de Historia da Medicina. Disponível em: < http:// www.sbhm.org.br/index.asp? $p=$ medicos view $\&$ codigo $=106>$. Acesso em: $22 \mathrm{fev}$. 2008.

MUSEU DA HISTÓRIA DA MEDICINA DO RIO GRANDE DO SUL. Colônia Itapuã, Hospital. Pesquisa Histórica. Porto Alegre. Disponível em: <http://www.muhm.org.br>. Acesso em 20 nov. 2007.

MURARD, L.; ZYLBERMAN, P. La Mission Rockefeller en France et la création du Comité National de Défense contre la tuberculose (1917-1923). Revue d'Histoire Moderne et Contemporaine, XXXIV, abriljunho, p. 257-281, 1987.

OBREGÓN, D. The anti-leprosy campaign in Colombia: the rhetoric of hygiene and science, 1920-1940. História, Ciências, Saúde - Manguinhos, Rio de Janeiro, 10, suplemento I, p.179-208, 2003.

. De "árbol maldito" a enfermedad curable: los médicos y la construcción de la lepra em Colombia, 1884-193. In: CUETO, Marcos (Ed.). Salud, cultura y sociedad en América Latina: nuevas perspectivas históricas, 1996, p.159-178.

PAIVA, C. H. A. A utopia burocrática: um estudo histórico-comparativo das políticas de saúde, Rio de Janeiro e São Paulo. Tese (Doutorado em Saúde Coletiva). Rio de Janeiro, Instituto de Medicina Social, Universidade do Estado do Rio de Janeiro, 2004.
PANDYA, S. The First International Leprosy Conference, Berlin, 1897: the politics of segregation. História, Ciências, Saúde - Manguinhos, Rio de Janeiro, 10, suplemento I, p. 161-177, 2003.

PINHO, A. M. dos S. M. Colônia do Bonfim no passado, hoje Hospital Aquiles Lisboa. Projeto Acervo. São Luís, 2007.

PINTO, H. O Posto de Caxias. Dispensário de Profilaxia da Lepra e Doenças Venéreas em Caxias. In: MIRANDA, C. (Org.). Os trabalhos de saneamento rural no Maranhão em 1923. Relatório apresentado pelo dr. Cássio Miranda, chefe interino do Serviço de Saneamento e Profilaxia Rural, à Diretoria do Serviço. Maranhão: Tipogravura Teixeira, 1925, p. 197-209 e 265-277.

PORTELA NUNES, P. Medicina, poder e produção intelectual: uma análise sociológica da medicina no Maranhão. Dissertação (Mestrado em Políticas Públicas). São Luís, Universidade Federal do Maranhão, Edições UFMA/Proin/CS, 2 vol., 2000.

RAMOS, P. M. de S. Relatório apresentado ao Sr. Dr. Getúlio Vargas, Presidente da República dos Estados Unidos do Brasil, pelo Dr. Paulo Martins de Souza Ramos, Interventor Federal do Maranhão, Imprensa Oficial, 1940.

SANTOS, V. S. M. dos. Pesquisa documental sobre a história da hanseníase no Brasil. História, Ciências, Saúde - Manguinhos, Rio de Janeiro, 10, suplemento I, p.415-426, 2003.

SANTOS FILHO, L. de C. História Geral da Medicina Brasileira. São Paulo: Hucitec/ Edusp, v. 2, 1991

SILVA ARAÚJO, O. A profilaxia da hanseníase e das doenças venéreas no Brasil e a atuação do Departamento Nacional de Saúde Pública. Arquivos de Higiene, Rio de Janeiro, 1 (2), p. 195-253, 1927.

SINGER, P.; CAMPOS, O.; OLIVEIRA, E. $M$. de. Prevenir e curar. O controle social através dos serviços de saúde. Rio de Janeiro: Forense-Universitária, 1978. 
VITAL BRAZII. Emilio Ribas. Archivos de Hygiene e Saude Publica, São Paulo, v. 1, n. 1, p. 7-12, jun.1936. Disponível em:
$<$ http://www2.prossiga.br/VitalBrazil/sobre/ ribas.PDF>. Acesso em: 22 fev. 2008.

\section{Resumen}

Contrapuntos de la historia de la enfermedad de Hansen en Brasil: Escenarios de estigma y confinamiento

Al discutir la lucha contra la enfermedad de Hansen en Brasil, en especial en San Pablo y en Maranhão, el trabajo enfocará las múltiples formas de la historia institucional y de la "cultura de reclusión" de los hansenianos (leprosos). Se critica la visión corriente de un escenario único de disciplina y vigilancia para, al contrario, sugerirse la existencia de escenarios cambiantes, marcados por conflictos, negociaciones y distintas propuestas de prevención o de combate a la enfermedad. El texto abordará las diferentes concepciones médicas y 'profanas' de la lepra, así como las propuestas y prácticas de intervención social en Brasil y, en particular, en los estados de San Pablo y de Maranhão, desde los primeros tiempos de la República hasta las primeras décadas de la Era Vargas. El combate a la enfermedad siempre desafió conceptos y convicciones sobre tratamiento, propagación, confinamiento y regeneración, bajo múltiples significados epidemiológicos, médicos, culturales y sociales, referidos al estigma de la enfermedad, del pecado y de la impureza. El texto procurará establecer algunos escenarios brasileños en los cuales se revelan las identidades colectivas deterioradas; la exclusión social; las políticas de confinamiento institucional y de regeneración de los enfermos.

Palabras-clave: Enfermedad de Hansen: San Pablo, Maranhão. Brasil: Primera República (18891930). Estado Nuevo (1930-1945). Identidades deterioradas. Políticas de confinamiento.

\section{Abstract}

Counterpoints in the history of Hansen's disease in Brazil: situations of stigma and seclusion

As the fight against leprosy in Brazil, particularly in the state of Maranhão, is singled out for analysis, this paper discusses the different medical and 'profane' conceptions of the disease, in addition to the proposals of public health intervention, always challenged by rival doctrines or convictions about contagion, diffusion, and treatment. The changing epidemiological, medical (i.e., the practices of isolation), social, and cultural views (particularly the stigma associated with the notions of sin, purity and danger) will help the search for singularities in Maranhão, the state's main 'sanitarians', political actors, and institutions, as well as for common historical elements, among Brazilian and other populations experiencing the disease.

Keywords: Leprosy. Brazilian states of São Paulo and Maranhão. Brazil: First Republican period (1889-1930). Brazil: Vargas Dictatorship (1930-1945). Stigma. Institutionalization.

Recebido para publicação em 06/03/2008. Aceito para publicação em 20/05/2008. 